\title{
II ZJAZD DZIENNIKARZY SŁOWIAŃSKICH W KRAKOWIE W 1899 ROKU $^{1}$
}

\author{
http://orcid.org/0000-0003-4256-3496
}

Adam Świątek

Uniwersytet Jagielloński w Krakowie (Polska)

\author{
ABSTRACT \\ SECOND CONGRESS OF SLAV JOURNALISTS IN CRACOW IN 1899
}

The aim of the article is to present the organization, course and consequences of the Second Congress of Slavic Journalists in Cracow in 1899. Due to the political nature of the congress, it will also be important to address the questions of the political goals held by the participating journalists and the attitude of the authorities to the event.

Keywords: journalism, press in the Habsburg Monarchy, Cracow, Slavianophilism.

Słowa kluczowe: dziennikarstwo, prasa w monarchii habsburskiej, Kraków, słowianofilstwo.

W ostatniej dekadzie XIX wieku rozkwit prasy europejskiej wszedł w nową fazę. To okres zarówno rozwoju instytucjonalnego (powstawanie lokalnych i międzynarodowych związków prasy, w przypadku Galicji - Towarzystwa Dziennikarzy Polskich we Lwowie w 1893 r.; dalej: TDP), jak i prób tworzenia trwałych sieci kontaktów między dziennikarzami z różnych krajów. Od roku 1894, gdy odbył się pierwszy Międzynarodowy Kongres Prasy w Antwerpii, w różnych miastach europejskich corocznie były organizowane kongresy skupiające po kilkuset dziennikarzy z różnych krajów. Udział dziennikarzy galicyjskich czy - szerzej - słowiańskich był w nim znikomy, ale kongresy te stały się inspiracją do podjęcia przez zamieszkujące monarchię habsburską narody słowiańskie inicjatywy organizowania podobnych zjazdów dziennikarzy słowiańskich.

II Zjazd Dziennikarzy Słowiańskich, który odbył się w dniach 23-25 września 1899 roku w Krakowie, jak i pozostałe zjazdy dziennikarzy słowiańskich

1 Artykuł powstał w ramach projektu OPUS 13, finansowanego przez Narodowe Centrum Nauki w Krakowie, pt. „Pomiędzy dwoma zjazdami w Pradze. Związki między Słowianami w Europie Środkowej i Południowo-Wschodniej w latach 1848-1908" (2017/25/B/HS3/00240).

Adres do korespondencji: adam.swiatek@uj.edu.pl 
organizowane niemal corocznie w latach 1898-1912² nie były dotychczas szerzej komentowane w polskiej literaturze naukowej. Wspominano ogólnie o nich raczej na marginesie innych badań: nad historią kontaktów polskich i zagranicznych słowianoznawców oraz słowianofilów ${ }^{3}$, nad przeszłością galicyjskich stowarzyszeń dziennikarskich ${ }^{4}$ oraz działań ministrów do spraw Galicji w kolejnych austriackich rządach ${ }^{5}$. O wiele bardziej historią zjazdów dziennikarzy słowiańskich interesowała się zagraniczna nauka, przede wszystkim czeska ${ }^{6}$, chorwacka ${ }^{7}$ i słoweńska ${ }^{8}$. Opracowania te opierały się przeważnie na analizie prasy odpowiednio: czeskiej, chorwackiej i słoweńskiej. Jak dotychczas, nie dokonano natomiast analogicznych badań na temat słowiańskich zjazdów dziennikarskich (w tym krakowskiego), opartych na polskiej prasie, jak i dokumentach przechowywanych w pogalicyjskich archiwach.

Tymczasem, zwłaszcza na temat II Zjazdu Dziennikarzy Słowiańskich w Krakowie, zachowało się całkiem sporo źródeł zarówno w samym Krakowie, jak i przede wszystkim we Lwowie. W niniejszym artykule wykorzystano akta lwowskiego Towarzystwa Dziennikarzy Polskich zgromadzone w Centralnym Archiwum Historycznym Ukrainy we Lwowie ${ }^{9}$. Drugą interesującą grupą dokumentów przechowy-

2 Kolejne zjazdy zorganizowano: w 1898 r. w Pradze, w 1899 r. w Krakowie, w 1901 r. w Dubrowniku, w 1902 r. w Lublanie, w 1903 r. w Pilznie, w 1905 r. w Opatiji, w 1906 r. w Hradyszczu, w 1908 r. ponownie w Lublanie, w 1910 r. w Sofii, w 1911 r. w Belgradzie i w 1912 r. w Pradze.

3 S. Bylina [et al.], Stosunki literackie polsko-czeskie i polsko-stowackie 1890-1939, red. J. Śleziński, Wrocław-Warszawa-Kraków-Gdańsk 1978, s. 30-31.

4 A. Toczek, Towarzystwo Dziennikarzy Polskich we Lwowie (1893-1918) [w:] Kraków-Lwów. Książki, czasopisma, biblioteki XIX i XX wieku, t. 6, cz. 2, red. J. Jarowiecki, Kraków 2003, s. 138; A. Toczek, Zwiazek Dziennikarzy Polskich we Lwowie (1909-1914) jako pierwsza korporacja dziennikarska o charakterze ogólnopolskim [w:] Kraków-Lwów. Książki, czasopisma, biblioteki XIX i XX wieku, t. 7, red. H. Ko sętka, Kraków 2005, s. 442-443.

5 D. Szymczak, Galicyjska ,ambasada” w Wiedniu. Dzieje ministerstwa dla Galicji 1871-1918, Poznań 2013, s. 203.

6 P. Vyšný, Neo-Slavism and the Czechs 1898-1914, Cambridge 1977, passim; J. Douša, Sjezd slovanských novinárů v Plzni v roce 1903 [w:] „Slavme slavně slávu Slávóv slavných”. Slovanství a česká kultura 19. století. Sborník př́spěvkỉ z 25. sympozia k problematice 19. století, Plzeň, 24.-26. února 2005, připr. Z. Hojda, M. Ottlová, R. Prahl, Praha 2006, s. 92-94.

7 D. Agičić, Hrvatski tisak o proslavi stote obljetnice rođenja Františeka Palackoga i Prvom kongresu slavenskih novinara Austro-Ugarske u Pragu 1898. godine [w:] Spomenica Ljube Bobana 1933.-1994., urednički odbor I. Goldstein, M. Kolar-Dimitrijević, M. Maticka, Zagreb 1996, s. 223-235; idem, Hrvatsko-češki odnosi na prijelazu iz 19. u 20. stoljeće, Zagreb 2000; idem, Slavenski novinarski kongresi 1903.-1908. godine [w:] Spomenica Filipa Potrebice, uredila M. Matije vić Sokol, Zagreb 2004, s. 321-330; S. Kale, „Poljaci, naša braća na sjeveru”. Hrvatska javnost o Poljacima 1860-1903, Zagreb 2018, s. 39-73, 103-108.

8 I. Gantar Godina, Neoslavizem in Slovenci, Ljubljana 1994, s. 71-85, 133-142, 163-172; eadem, Ljubljana - gostiteljica 4. vseslovanskega časnikarskega kongresa maja 1902, „Kronika” (Ljubljana), letnik 50, 2002, s. 375-384; eadem, Ob 100. obletnici VIII. vseslovanskega časnikarskega kongresa septembra 1908 w Ljubljani, „Kronika” (Ljubljana), letnik 57, 2009, s. 455-464.

9 Центральний державний історичний архів України у Львові (dalej: ЦДІАУЛ), ф. 466: Товариство польських журналістів, м. Львів. Do dzisiejszych czasów nie zachowały się w kompletnym stanie wszystkie drukowane sprawozdania ТDР. Сzęść sprawozdań posiada ЦДІАУЛ, a część Biblioteka Jagiellońska w Krakowie. Por. A. Toczek, Towarzystwo Dziennikarzy Polskich..., s. 129, przyp. 13. 
wanych w lwowskim archiwum są akta Namiestnictwa Galicyjskiego ${ }^{10}$, które wraz ze zgromadzonymi w II Oddziale Archiwum Narodowego w Krakowie aktami CK Dyrekcji Policji1 ${ }^{11}$ ukazują obawy i próby przeciwdziałania organizacji zjazdu przez władze państwowe. W III Oddziale Archiwum Narodowego w Krakowie ponadto znajduje się fragmentaryczna korespondencja komitetu organizacyjnego z władzami miasta Krakowa na temat pozyskania funduszy ${ }^{12}$. W Bibliotece Jagiellońskiej z kolei przechowywana jest licząca 80 stron publikacja wydana jako pokłosie zjazdu. Zawiera ona opis przygotowań i przebiegu zjazdu, program oraz spis uczestników ${ }^{13}$. Ponadto o zjeździe rozpisywała się prasa zarówno galicyjska ${ }^{14}$, jak i zagraniczna.

Celem niniejszego artykułu jest przybliżenie kulisów organizacji, przebiegu i skutków II Zjazdu Dziennikarzy Słowiańskich w Krakowie. Ważna będzie także próba odpowiedzi na pytanie o polityczne cele, jakie dziennikarze sobie stawiali, oraz o stosunek władz krajowych do organizowanego zjazdu.

\section{OKOLICZNOŚCI ORGANIZACJI ZJAZDU}

Pomysł organizacji kongresu dziennikarskiego w Krakowie zrodził się w czerwcu 1898 roku w Pradze. Stolica Korony św. Wacława celebrowała wówczas jubileusz 100. rocznicy urodzin Františka Palackiego, wielkiego słowianofila i organizatora pamiętnego Zjazdu Słowiańskiego w Pradze w 1848 roku, którego z kolei 50. rocznica przypadała równolegle. $Z$ tej to okazji obchody Palackiego zostały uświetnione organizacją I Zjazdu Dziennikarzy Słowiańskich w dniu 19 czerwca 1898 roku. Należy mieć na uwadze, że wydarzenia te miały miejsce zaledwie rok po wprowadzeniu

O krakowskim zjeździe pisano w sprawozdaniu za lata 1899-1900, zob. ЦДІАУЛ, ф. 466, оп. 1, спр. 11: Звіт про діялність товариства за 1899-1900 рр.

10 ЦДІАУЛ, ф. 146: Галицьке намісництво, оп. 6, спр. 1275: Донесення, листування, звіти та інші документи таємного діловодства президіального відділу, 1899, k. 593; ibidem, оп. 7, спр. 4771: Переписка с Дырекцией полиции и комитетом по организации II сьезда представителей словянской пресы о запрещении полицией проведення пресы в Кракове 1899, k. 1-44.

11 Archiwum Narodowe w Krakowie (dalej: ANKr.), zesp. 29/247: C.K. Dyrekcja Policji w Krakowie, sygn. 56: Akta prezydialne 1902 nr 17-1058.

12 ANKr., zesp. 29/576/0: Obchody i uroczystości krakowskie - zbiór szczątków zespołów akt komitetów obchodów, sygn. 43: Akta różnych uroczystości krakowskich (pogrzeby, obchody, jubileusze, zjazdy), teka 13: Zjazd Dziennikarzy Słowiańskich, k. 1323-1329; ibidem, sygn. 151: Zjazd Dziennikarzy Słowiańskich II Zjazd w Krakowie 1899, k. 1-10.

13 Drugi Zjazd Dziennikarzy Stowiańskich w Krakowie, Kraków 1900.

14 Por. m.in.: „Czas”, 23 IX 1899, nr 217, s. 2; 24 IX 1899, nr 218 z, s. 1-2; nadzwyczajny dodatek do nr. 218, s. 2; 26 IX 1899, nr 219, s. 1-2; nadzwyczajny dodatek do nr. 219, s. 1-2; 27 IX 1899 , nr 220, s. 2; „Dziennik Polski”, 24 IX 1899, nr 265, s. 2-3; 25 IX 1899, nr 266, s. 1-2; 9 IX 1899 , nr 267, s. 1, 2; 27 IX 1899, nr 268, s. 2; 28 IX 1899, nr 269, s. 1; „Gazeta Lwowska”, 24 IX 1899, nr 218, s. 5; 26 IX 1899, nr 219, s. 2-3; 27 IX 1899, nr 220, s. 1-2; „Gazeta Narodowa”, 24 IX 1899, nr 265, s. 3; 26 IX 1899, nr 267, s. 1-2; 27 IX 1899, nr 268, s. 1, 2; „Głos Narodu”, 22 IX 1899, nr 215, s. 1; 23 IX 1899, nr 216, s. 1; 25 IX 1899, nr 217, s. 1-4; 26 IX 1899, nr 218, s. 1-3; 27 IX 1899, nr 219, s. 1; „Nowa Reforma”, 24 IX 1899, nr 218, s. 1-2, 2-3; 26 IX 1899, nr 219, s. 1-2, 3; 27 IX 1899, nr 220 , s. 2. 
przez szefa rządu austriackiego, Kazimierza Badeniego, rozporządzeń językowych dla Czech i Moraw, które wywołały wśród przedlitawskich Niemców (którzy poczuli zagrożenie swojej dotychczas dominującej pozycji tak w monarchii, jak i w krajach czeskich) wzrost tendencji antyczeskich i generalnie antysłowiańskich, co polski polityk przypłacił utratą stanowiska. Polityka Badeniego przyciągnęła jednak do większości rządzącej posłów młodoczeskich, dotychczas bojkotujących udział w Radzie Państwa. Najogólniej rzecz ujmując, mimo kryzysu politycznego w państwie, znacząco ociepliły się stosunki między politykami i opinią publiczną polską i czeską ${ }^{15}$. Nic więc dziwnego, że zjazd praski choć miał dotyczyć dziennikarstwa, w rzeczywistości poruszał też sprawy polityczne. Otóż uczestnicy I Zjazdu Słowiańskich Dziennikarzy w przyjętych uchwałach przyrzekli sobie zwalczać wszelkie różnice dzielące narodowości słowiańskie w Austro-Węgrzech i zapomnieć o dawnych krzywdach ${ }^{16}$. Podkreślano, że słowiańskie narody nie będą dążyć do zdominowania innych narodowości, ale „uporczywie bronić się będą przeciw każdemu gwałtowi”'17. Deklarowano, że celem współpracy słowiańskich narodowości powinno być doprowadzenie do tego,

[...] ażeby monarchia austro-węgierska doszła nareszcie do swego naturalnego przeznaczenia i stała się zaszczytną przystanią politycznej swobody dla wszystkich swoich, w rozwoju uprawnionych narodów, pozostających w takich warunkach rządu państwowego, ażeby rozwijać się mogły w duchu postępu i oświaty ludzkiej, aby wzrastał ich dobrobyt ekonomiczny, i aby ich życie społeczne mogło się wznieść do wyżyny zupełnej godności ludzkiej ${ }^{18}$.

Oprócz celów natury ogólnej wyznaczono sobie cele szczegółowe, to jest potępiać każde przypadki prześladowania prasy; wspierać rozwój przemysłu słowiańskiego (pod czym rozumiano m.in. przeciwdziałanie wykupywaniu gruntów rolnych w krajach słowiańskich przez nie-Słowian); założenie własnej, słowiańskiej agencji prasowej; zadbanie o prawidłową pisownię nazw topograficznych, które w słowiańskich gazetach są zniekształcane z powodu czerpania informacji za pośrednictwem wiedeńskiej agencji prasowej, a więc w języku niemieckim; wreszcie wystąpienie przeciwko zakazowi przesyłania gazet z jednego krańca monarchii do drugiego (tzw. debit pocztowy $)^{19}$.

W zjeździe praskim wzięła udział dość liczna reprezentacja polskiego dziennikarstwa, w tym także władze lwowskiego TDP: prezes Liberat Zajączkowski, wiceprezes Michał Chyliński, członkowie zarządu: Edmund Kolbuszowski, Karol Kucharski, Bronisław Laskownicki i Aleksander Milski, a także zwykli członkowie: Ludwik Masłowski i dr Kazimierz Ostaszewski-Barański. Szczególną rolę w zjeździe praskim odegrał redaktor krakowskiego „Czasu” Michał Chyliński, którego wybrano

15 Szerzej: J. Gruchała, Kolo Polskie w austriackiej Radzie Państwa wobec kwestii czeskiej i Śląska Cieszyńskiego (1879-1899), Wrocław [et al.] 1982, s. 57-79.

16 Sprawozdanie Towarzystwa Dziennikarzy Polskich we Lwowie za czas od dnia 17. kwietnia 1898 roku do dnia 14. maja 1899 roku [...], Lwów 1899 (dalej: Sprawozdanie TDP... 1899), s. 13-14.

17 Ibidem, s. 14.

18 Ibidem.

19 Ibidem, s. 14-15. 
wiceprezesem I Zjazdu. Tam po raz pierwszy zaproponowano, by organizatorem kolejnego zjazdu dziennikarzy słowiańskich został Kraków ${ }^{20}$.

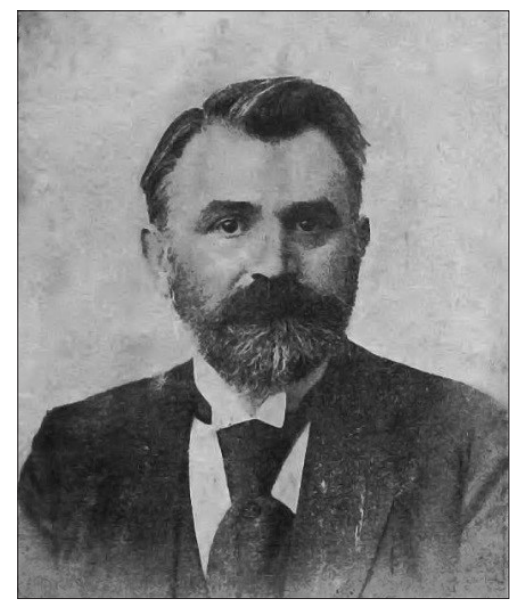

Il. 1. Michał Chyliński

Źródło: „Nowości Illustrowane”, 20 I 1906, nr 3, s. 7.

Niedługo po zakończeniu zjazdu w Pradze miało miejsce jeszcze jedno wydarzenie, które dowiodło zacieśniających się stosunków polsko-czeskich. Mianowicie w dniach 26-27 czerwca 1898 roku odbyły się obchody Mickiewiczowskie w Krakowie, które nie były pozbawione akcentów słowianofilskich. Na uroczystym odsłonięciu pierwszego na ziemiach polskich pomnika Adama Mickiewicza zjawily się delegacje z Czech i Słowacji, w tym także dziennikarze rok później obecni na zjeździe dziennikarskim: František Hovorka, redaktor „Hlasa Naroda” oraz Svetozár Hurban-Vajanský, redaktor słowackiej gazety „Národnie noviny”. Prezydent miasta Pragi Vladimir Srb złożył wówczas srebrną gałązkę lipową przy grobie Mickiewicza na Wawelu, a w trakcie bankietu na cześć gości z Czech wznoszono toast za porozumienie czesko-polskie ${ }^{21}$.

\section{PRZYGOTOWANIA DO ZJAZDU}

Przygotowania do organizacji zjazdu krakowskiego rozpoczęły się z początkiem roku 1899. Pod koniec stycznia redaktor „Czasu” Michał Chyliński i prezes TDP Liberat Zajączkowski jak donosiła prasa - udali się do Wiednia, a następnie

20 Sprawozdanie TDP... 1899, s. 6-7.

${ }^{21}$ A. Leśnodorska, Z. Mleczkówna, Pomnik Adama Mickiewicza w Krakowie [w:] Kraków Mickiewiczowi, red. D. Rederowa, Kraków 1956, s. 149-153. 
do Pragi, celem omówienia planów organizacji kolejnego zjazdu słowiańskiego ${ }^{22}$. 3 lutego 1899 roku w siedzibie Związku Dziennikarzy Czeskich w Pradze (Spolek českých žurnalistů) zorganizowano spotkanie z polskimi gośćmi, w którym wzięli udział przedstawiciele najważniejszych czeskich dzienników. Komitet organizacyjny pierwszego zjazdu przedstawił sprawozdanie z odbytego kongresu, a następnie jednogłośnie uchwalono, że: kolejny zjazd zostanie zorganizowany w Krakowie z końcem czerwca lub początkiem lipca; uczestnicy sami sfinansują swój udział w kongresie; językiem obrad będzie polski (zgodnie z zasadą, że obrady każdego z kongresów odbywają się w języku gospodarza, ale każdy może przemawiać w swoim języku); komitet czeski prześle do Krakowa wszystkie niezbędne dokumenty; w końcu że program przyszłego zjazdu zostanie uchwalony w marcu lub kwietniu na spotkaniu roboczym w Wiedniu, na którym będą obecni dziennikarze polscy, czescy, słoweńscy i chorwaccy. Spotkanie w Pradze zwieńczono ucztą na cześć Chylińskiego i Zajączkowskiego, w trakcie której podnoszono toasty za polsko-czeskie braterstwo ${ }^{23}$.

Komitet organizacyjny zjazdu powołano na posiedzeniu TDP, które odbyło się nazajutrz po organizowanym w dniu 7 lutego 1899 roku we Lwowie balu prasy. Szefostwo komitetu powierzono Michałowi Chylińskiemu ${ }^{24}$. Początkowo prace nad kongresem posuwały się bardzo powoli, trudno było też podtrzymać stałą współpracę z poznanymi na zjeździe praskim dziennikarzami. Świadczy o tym fakt, że ani w marcu, ani w kwietniu nie doszło do planowanego spotkania dziennikarzy z różnych krajów słowiańskich w Wiedniu. Dziennikarzom słowiańskim nie udało się również spotkać na zorganizowanym w dniach 5-7 kwietnia Międzynarodowym Kongresie Dziennikarzy w Rzymie, zabrakło tam bowiem zupełnie Czechów, a Polaków przyjechało raptem kilku, głównie z Galicji ${ }^{25}$.

Pierwsze spotkanie konstytuujące komitet organizacyjny przyszłego zjazdu krakowskiego odbyło się dopiero w dniu 9 kwietnia 1899 roku w Krakowie. Chyliński zaprosił do komitetu organizacyjnego przedstawicieli krakowskich gazet: „Czasu” (dr. Antoniego Beaupré i Rudolfa Starzewskiego), liberalnej „Nowej Reformy” (Władysława Prokescha, Michała Konopińskiego) i katolickiego „Głosu Narodu” (Kazimierza Ehrenberga i dr. Włodzimierza Lewickiego). Sekretarzem komitetu obrano Prokescha i zmieniono datę kongresu na 23-25 września. Postanowiono współpracować z TDP we Lwowie oraz komitetem organizacyjnym ubiegłorocznego zjazdu praskiego ${ }^{26}$. Według poufnych informacji zebranych przez lwowską policję na kolejnym zebraniu TDP 14 kwietnia nie podjęto żadnych kroków, z wyjątkiem wydelegowania do Krakowa: Liberata Zajączkowskiego, Kazimierza Skrzyńskiego i Stanisława Schnürr-Pepłowskiego ${ }^{27}$.

22 „Czas”, 28 I 1899, nr 23, s. 2.

23 „Głos Narodu”, 7 II 1899, nr 30, s. 4; „Czas”, 12 II 1899, nr 35, s. 2.

24 „Czas”, 12 II 1899, nr 35, s. 2.

25 „Czas”, 7 IV 1899, nr 79, s. 3; 8 IV 1899, nr 80, s. 2. Przebieg kongresu: „Czas”, 9 IV 1899, nr 81, s. 1-2; 11 IV 1899, nr 82, s. 2; 21 IV 1899, nr 91, s. 1-2; 23 IV 1899, nr 93, s. 3. W polskich gazetach podkreślano, że zjazd zdominowali Francuzi i Niemcy.

26 „Czas”, 11 IV 1899, nr 82, s. 2; ANKr., zesp. 29/247, sygn. 56, k. 968; Drugi Zjazd..., s. 1.

27 ANKr., zesp. 29/247, sygn. 56, k. 955. 
19 czerwca odbyło się w Krakowie spotkanie komitetu organizacyjnego, na które przybyli Zajączkowski i Schnürr-Pepłowski. Odczytali na nim list od wydziału TDP, informujący o deklaracji przystąpienia do komitetu organizacyjnego redakcji lwowskich gazet: „Gazety Lwowskiej” (Kazimierz Zielonka), „Gazety Narodowej” (Aleksander Vogel), „Dziennika Polskiego” (Kazimierz Ostaszewski-Barański), „Ruchu Katolickiego” (Zygmunt Skirmunt), „Przeglądu” (Ludwik Masłowski) i niejako na wyrost także „Słowa Polskiego"28 (Tadeusz Romanowicz). Komitet organizacyjny w Krakowie uchwalił, by dokooptować do szerszego komitetu programowego także ludzi nauki i kultury głównie związanych z Krakowem: Michała Bałuckiego, Kazimierza Bartoszewicza, Kazimierza Czapelskiego, prof. Włodzimierza Czerkawskiego, hr. Ludwika Dębickiego, ks. Teofila Flisa, Antoniego i Piotra Górskich, Józefa Hopcasa, prof. Włodzimierza L. Jaworskiego, Aleksandra Karcza, Stanisława Kopernickiego, dyrektora Teatru Miejskiego w Krakowie Józefa Kotarbińskiego, ks. Włodzimierza Ledóchowskiego, Ignacego „Sewera” Maciejowskiego, prof. Kazimierza Morawskiego, Jerzego hr. Mycielskiego, prof. Czesława Pieniążka, hr. Michała Roztworowskiego, Lucjana Rydla, dr. Augusta Sokołowskiego, Kazimierza Tetmajera, dr. Stanisława Tomkowicza i prof. Mariana Zdziechowskiego. Do komisji programowej z komitetu organizacyjnego weszli natomiast dr Antoni Beaupré, Kazimierz Ehrenberg i Michał Konopiński ${ }^{29}$. W dniu następnym delegaci komitetu organizacyjnego udali się do prezydenta Krakowa Józefa Friedleina i oficjalnie zawiadomili o planowanym kongresie ${ }^{30}$. Wprowadzenie do komitetu organizacyjnego słowianofilów związanych z Uniwersytetem Jagiellońskim, w tym Morawskiego, Zdziechowskiego czy Sokołowskiego, znacząco poszerzyło horyzonty oczekiwań w stosunku do rezultatów kongresu.

25 czerwca odbyło się spotkanie komitetu organizacyjnego, na którym omówiono, jakie referaty zostały zgłoszone przez dziennikarzy czeskich i powierzono opracować wystąpienia Sokołowskiemu, Beaupré oraz Ledóchowskiemu. Sokołowskiego i Ledóchowskiego, a ponadto Zdziechowskiego i Jaworskiego postanowiono dokooptować do ścisłego komitetu organizacyjnego zjazdu, a Kotarbiński obiecał przygotować specjalne przedstawienie dla gości w Teatrze Miejskim ${ }^{31}$. Na kolejnym posiedzeniu komitetu, w dniu 29 czerwca, Sokołowski, Beaupré i Ledóchowski przedstawili szkice swoich wystąpień i uchwalono, by podać do publicznej wiadomości, że 15 sierpnia upłynie termin nadsyłania zgłoszeń kolejnych referatów. Chyliński oświadczył natomiast, że zgłosiło się do niego grono zwolenników ks. Stanisława Stojałowskiego na czele z adwokatem dr. Antonim Dobiją, z informacją o planowanym przez nich na dzień 8 września 1899 roku zjeździe słowiańskim w Krakowie. Komitet po przeprowadzonej dyskusji jednogłośnie odciął się jednak od tej inicjatywy i wyraził opinię, że organizowanie parę dni przed zjazdem dziennikarzy

28 Drugi Zjazd..., s. 1-2; „Głos Narodu”, 20 VI 1899, nr 136, s. 4; „Nowa Reforma”, 22 VI 1899, nr 140, s. 2.

29 „Głos Narodu”, 20 VI 1899, nr 136, s. 4; „Słowo Polskie”, 20 VI 1899, nr 144, s. 5. Por. Drugi Zjazd..., s. 1-2.

30 „Głos Narodu”, 20 VI 1899, nr 13, s. 4.

31 „Czas”, 27 VI 1899, nr 144, s. 2. 
słowiańskich zjazdu słowiańskiego jest zbyteczne (zjazd ten ostatecznie się nie odbył $)^{32}$. Tym samym za organizację kongresu odpowiadały głównie galicyjskie siły konserwatywne i demokratyczne, odcinając się od środowisk radykalnych: stojałowczyków, ale także od socjalistów.

Prace nad kongresem przyspieszyły w lipcu. 7 lipca organizatorzy zjazdu zwrócili się do Rady Miasta Krakowa o subwencję ${ }^{33}$ i otrzymali 3 tys. złr $^{34}$. Na spotkaniu komitetu organizacyjnego, 12 lipca, ustalono, że uczestnikiem zjazdu może być każdy dziennikarz słowiański mieszkający i pracujący w Austro-Węgrzech, który potwierdzi swój udział do 1 września i uiści opłatę wysokości 5 złr. Zaproszenia postanowiono wysłać do tych dziennikarzy, których miało rekomendować TDP oraz Związek Dziennikarzy Czeskich ${ }^{35}$. W ten sposób organizatorzy wykluczyli z udziału dziennikarzy spoza monarchii oraz osoby nieprzychylne idei kongresu czy organizatorom. Ponadto konieczność weryfikacji uczestników z Galicji przez TDP oznaczała ewentualną możliwość cenzurowania zgłoszeń między innymi ze strony ruskich (ukraińskich) dziennikarzy. W aktach TDP nie znajdujemy jednak żadnych dokumentów, które by potwierdziły, że ruscy dziennikarze (narodowcy, rusofile czy socjaliści) w ogóle starali się o udział w kongresie. Prócz tego oficjalnie ze zjazdu wycofała się redakcja „Słowa Polskiego”, co nie było zaskoczeniem, uwzględniwszy że już rok wcześniej gazeta negatywnie oceniała zjazd praski, krytykując go za antyaustriacki i zarazem prorosyjski wydźwięk. Teraz redaktor "Słowa Polskiego", Tadeusz Romanowicz, ogłosił list adresowany do Chylińskiego, w którym zakwestionował zasadność organizacji zjazdu w ogóle ${ }^{36}$.

Przez całe lato napływały zgłoszenia dziennikarzy słowiańskich na zjazd za pośrednictwem redakcji gazet lub komitetów. Związek Dziennikarzy Czeskich powołał specjalny komitet, składający się z redaktorów czeskich gazet, który był odpowiedzialny za zorganizowanie licznej delegacji czeskiej na zjazd ${ }^{37}$. Z kolei „Národnie noviny" z Turczańskiego św. Marcina wysłały zgłoszenie dziennikarzy słowackich, w tym znanego literata słowackiego i zarazem rusofila Svetozára Hurbana-Vajanskiego, który zgłosił chęć wystąpienia z referatem pt. „O słowiańskiej wzajemności w dziennikarstwie" ${ }^{38}$. Rozważano nawet zaproponować Vajanskiemu przewodniczenie zjazdowi, ale ostatecznie Kazimierz Ostaszewski-Barański zaoponował przeciwko temu pomysłowi ze względu na panslawistyczne zapatrywania słowackiego literata $^{39}$. Ostatecznie zdecydowano, by prosić na przewodniczącego władającego ję-

32 „Czas”, 1 VII 1899, nr 147, s. 2; „Głos Narodu”, 30 VI 1899, nr 145, s. 4; Drugi Zjazd.., s. 2; ANKr., zesp. 29/247, sygn. 56, k. 952.

33 ANKr. zesp. 29/576/0, sygn. 151: Zjazd Dziennikarzy Słowiańskich II Zjazd w Krakowie 1899, k. 7.

34 Drugi Zjazd..., s. 3.

35 „Czas”, 14 VII 1899, nr 158, s. 2; „Głos Narodu”, 14 VII 1899, nr 157, s. 4; Drugi Zjazd..., s. 3.

36 „Słowo Polskie”, 2 VII 1899, nr 155, cyt. za: ANKr., zesp. 29/247, sygn. 56, k. 951.

37 „Nowa Reforma”, 19 VIII 1899, nr 188, s. 2.

38 „Nowa Reforma”, 3 IX 1899, nr 201, s. 3; Korešpondencia Svetozára Hurbana Vajanského II (Výber listov z rokov 1890-1916), ed. P. Petrus, Bratislava 1972, s. 448.

39 Szerzej o zapatrywaniach Vajanskiego: D. Kodajová, Rusko v slovenskej politike na prelome 19. a 20. storočia. Vajanský verzus Masaryk [w:] T. Ivantyšynová [a kol.], Mýtus, stereotyp, obraz. Rusko v slovenských dejinách a kultúre, Bratislava 2011, s. 16-19. 
zykiem polskim Czecha - Františka Hovorkę, do czego ostatecznie jednak nie doszło (prezesem kongresu zostanie później wybrany Emil Bretter).

$\mathrm{O}$ niedoszłej roli Vajanskiego na zjeździe momentalnie natomiast doniosła Namiestnictwu we Lwowie krakowska policja, śledząca od samego początku w prasie i za pomocą informatorów przygotowania do zjazdu ${ }^{40}$. Powiadomienie to wyszło z Krakowa 17 września, a więc na dzień przed oficjalnym zgłoszeniem policji przez sam komitet programu planowanego zjazdu ${ }^{41}$. Mimo zdementowania informacji o roli Vajanskiego na zjeździe, w sprawę osobiście zaangażował się sam szef rządu Franz Thun, który oświadczył ministrowi ds. Galicji Adamowi Jędrzejowiczowi, że „chce, aby w zjeździe uczestniczyli tylko austr[iaccy] obywatele” [podkr. oryg.] ${ }^{42}$. 20 września policja zaprosiła na spotkanie redaktora Chylińskiego, na którym był obecny także delegat namiestnika Leona Pinińskiego - Kazimierz Laskowski. Chylińskiemu oznajmiono - mimo iż pozostały tylko trzy dni do zjazdu - że obywatele węgierscy nie mogą wziąć udziału w kongresie. Polecono albo przełożyć zjazd, albo powiadomić telegramem gości z Zalitawii o odwołaniu ich przyjazdu. W przypadku niezastosowania się do poleceń zagrożono, że przybysze z Węgier (Słowacy i Chorwaci) mogą zostać przymusowo odesłani do domu. Chyliński tłumaczył, że część gości jest już w drodze do Krakowa, ale nie mogąc przeciwstawić się wydanej decyzji, poprosił jedynie, by przedstawiono mu ją na piśmie ${ }^{43} .21$ września Laskowski zapytywał prezydium Namiestnictwa, czy nie ma przeszkód, by wydać rezolucję ${ }^{44}$. Będzie ona później podstawą wszczęcia przez komitet organizacyjny zjazdu procedury odwoławczej na drodze oficjalnej.

W rezolucji wyraźnie sformułowano zapis, że w ,zjeździe mogą wziąć udział wyłącznie tylko obywatele austryjaccy [podkr. oryg.]" ${ }^{45}$. Aby wyegzekwować to postanowienie, władze planowały wysłać komisarza rządowego na obrady zjazdu, który miał doprowadzić do deportacji niepożądanych przez władze gości kongresu. Ostatecznie jednak krakowskiej policji udało się powstrzymać przyjazd komisarza. Jej dyrektor i zarazem radca rządu, Zenon Korotkiewicz, w liście do namiestnictwa tłumaczył, że na zjeździe w Pradze komisarza nie było, ponadto „niepotrzebna zresztą dopuścić do takiego odium, aby komisarz rządowy miał ewentualnie ze sali kazać wydać takich obcych dziennikarzy"46. Policja uzyskała natomiast zapewnienie od Chylińskiego, że goście z Węgier nie będą w trakcie obrad w ogóle zabierać głosu ${ }^{47}$. Goście z Węgier przyjechali zatem do Krakowa ${ }^{48}$, ale komitet organizacyjny zjazdu, mimo wydrukowania już programu, musiał go zmienić. Zaplanowane na 23 września

40 ANKr., zesp. 29/247, sygn. 56, k. 935; ЦДІАУЛ, ф. 146, оп. 7, спр. 4771, k. 1-2.

${ }^{41}$ ANKr., zesp. 29/247, sygn. 56, k. 875-878.

42 ANKr., zesp. 29/247, sygn. 56, k. 880.

43 Ibidem, k. 881-882; ЦДІАУЛ, ф. 146, оп. 7, спр. 4771, k. 7.

44 ЦДІАУЛ, ф. 146, оп. 6, спр. 1275, k. 593.

45 ANKr., zesp. 29/247, sygn. 56, k. 886.

46 ЦДІАУЛ, ф. 146, оп. 7, спр. 4771, k. 12.

47 Ibidem, k. 11-13; ANKr., zesp. 29/247, sygn. 56, 853, 861-862.

48 Pełną listę przyjezdnych ogłoszono w: „Czas”, 23 IX 1899, nr 217, s. 3. Por. „Nowa Reforma”,

23 IX 1899, nr 217, s. 2; Drugi zjazd..., s. 6-9. Podawano łącznie 96 uczestników zjazdu. 
wystąpienie Svetozára Hurbana-Vajanskiego zostało odwołane. Komitet organizacyjny zjazdu już na następny dzień (21 IX) wniósł rekurs przeciw wydanej rezolucji, a namiestnictwo kazało dosłać odpowiednie akta, wnieść opłaty skarbowe, tym samym spowalniając swoją odpowiedź na sprzeciw komitetu ${ }^{49}$.

Należy też podkreślić, że przebieg zjazdu był pod stałą obserwacją policji. W aktach namiestnictwa zachowały się szczegółowe raporty dyrektora policji Zenona Korotkiewicza, które ten codziennie wysyłał do ministerstwa spraw wewnętrznych, cytując przemowy i opisując zachowania uczestników ${ }^{50}$.

\section{PRZEBIEG ZJAZDU}

Program zjazdu był bardzo intensywny. W dniu 22 września goście z Czech i innych krajów słowiańskich zostali przywitani na dworcu przez mieszkańców Krakowa, w tym krakowskich Czechów, okrzykami: „Na zdar - niech żyją!”. Oficjalne powitanie wygłosił w budynku dworca prezes komitetu Michał Chyliński słowami:

[...] jakkolwiek się w najbliższej przyszłości ułożą stosunki polityczne, jakiekolwiek losy nas czekają: dobre, czy złe, triumfy czy zawody, trzymajmy się razem i nie rozbijajmy się. Jednością silną nie damy się zwyciężyć. Sursum corda! [W górę serca! - A.Ś.] $]^{51}$.

Następnie goście udali się do krakowskich hoteli: Grand, Saskiego, Krakowskiego, Polskiego i Pollera. O 21 wieczorem 22 września zorganizowano dla przybyłych kolację w Hotelu Saskim.

W sobotę 23 września zjazd zainaugurowano mszą świętą w kościele Mariackim, którą odprawił ks. Juraj Biankini, poseł z Zadaru w Dalmacji do Rady Państwa oraz redaktor „Narodnego listu”. Następnie udano się do Rady Miejskiej, gdzie powitał gości prezydent Krakowa Józef Friedlein. Chyliński zainaugurował I posiedzenie, podkreślając, że bieżąca sytuacja polityczna wymaga „wzajemnego zbliżenia się, porozumienia, wspólnej pracy i wspólnej obrony" ${ }^{2}$. Również Liberat Zajączkowski w swoim przemówieniu nie krył, że ,zjazd dziennikarzy słowiańskich to kongres patriotów i polityków narodowych, to wielka poufna narada, której znaczenie w tem, że mamy możność wzajemnego porozumienia się i wniknięcia w tajniki interesów naszych politycznych"53. Mimo odważnych deklaracji nie zabrakło jednak lojalistycznych tonów - otóż pierwszą rzeczą, którą uchwalono, było wysłanie telegramów „Z wyrazami hołdu, czci i uległości do Najj[aśniejszego] Pana”, a także do ministrów spraw wewnętrznych Josefa Kaizla i ds. Galicji Adama Jędrzejowicza ${ }^{54}$. Do tych

49 ЦДІАУЛ, ф. 146, оп. 7, спр. 4771, k. 15-19.

50 Ibidem, k. 8-10: [program zjazdu], 24-30: [raport z 23 X 1899], 32-34: [wykaz uczestników], 36-36: [raport z 24 X 1899], 41-43: [raport z 25 X 1899]. Policja odnotowała 93 uczestników zjazdu.

51 „Czas”, 24 IX 1899, nr 218, s. 1.

52 Drugi Zjazd..., s. 13.

53 Ibidem, s. 15.

54 Ibidem, s. 16. 
ostatnich - jak zauważył Damian Szymczak - wysłano telegramy raczej ironicznie, zważywszy na czynienie utrudnień w organizacji zjazdu tuż przed jego inauguracją ${ }^{55}$. Pisano bowiem o obu ministrach przewrotnie jako o rzekomych reprezentantach „przyświecającej Zjazdowi idei politycznego sojuszu narodów słowiańskich, opartego na rzeczywistej wolności równych prawach dla siebie i drugich" ${ }^{56}$. Później zaproponowano także wysłanie telegramu do Juliana Dunajewskiego w dowód wdzięczności za otaczanie „opieką interesów narodów słowiańskich" ${ }^{57}$. Następnie uchwalono regulamin obrad i wybrano na przewodniczącego kongresu redaktora praskiej gazety „Politik” - Emila Brettera, wiceprezesami zostali: ks. Juraj Biankini oraz redaktor „Gazety Narodowej” Platon Kostecki (,znany patriarcha polskiego dziennikarstwa”jak o nim pisano), na sekretarza wybrano Schnürr-Pepłowskiego, a jego zastępcami zostali Jan Langner i František Hovorka ${ }^{58}$. Po odczytaniu telegramów przeważnie od różnych osobistości czeskiego życia publicznego, przystąpiono do obrad.

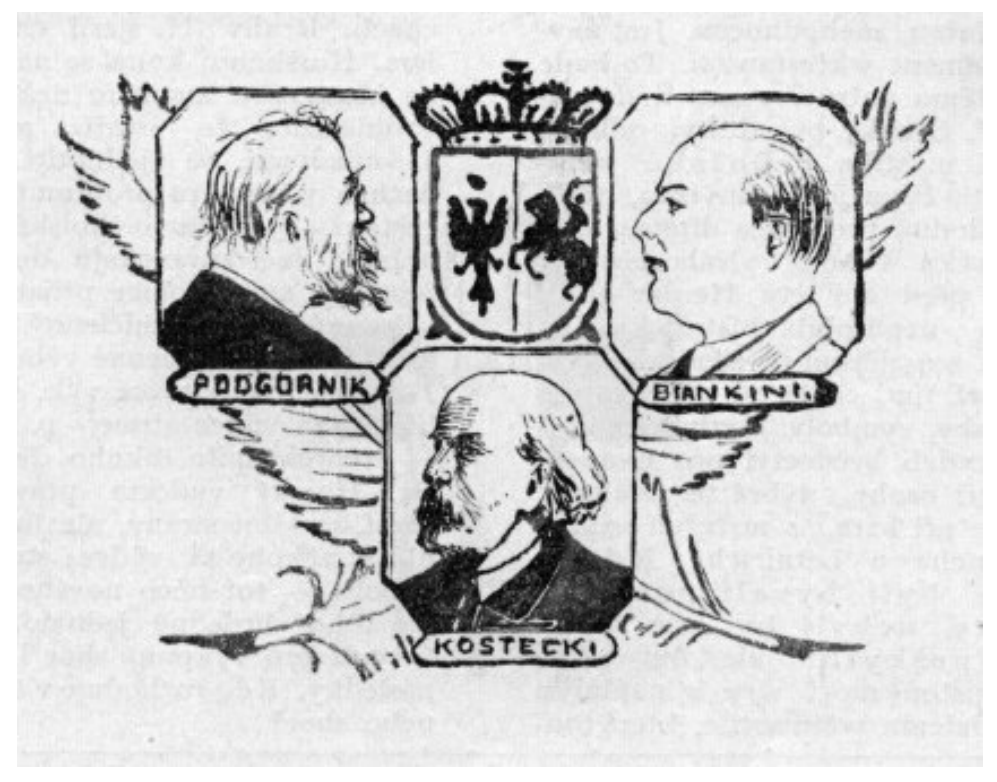

Il. 2. Redaktor „Slavisches Echo” Franc Podgornik, redaktor „Narodnego listu” ks. Juraj Biankini oraz redaktor „Gazety Narodowej” Platon Kostecki

Źródło: Sjezd slovanských novinárů v Krakově ve dnech 23., 24., 25. záři 1899, „Nový život”, R. 4, 1899, s. 287.

\footnotetext{
D. Szymczak, op. cit., s. 203.

66 „Czas”, 24 IX 1899, nr 218, s. 2.

57 Ibidem; Drugi Zjazd..., s. 28.

58 „Czas”, 24 IX 1899, nr 218, nadzwyczajny dodatek, s. 2.
} 
Pierwszy referat wygłosił Antoni Beaupré, który dowodził, że idea słowiańskiej solidarności została wypaczona przez Rosję, która posłużyła się tą ideą do jednego „z najsroższych prześladowań narodowych, jakie pamiętają dzieje ludzkości” ${ }^{59}$. Tym tłumaczył „uzasadnioną” nieufność Polaków do Rosji. Tym samym podkreślił, że solidarność słowiańska nie może prowadzić do zatracenia indywidualizmu narodowego, ale na nim się powinna przede wszystkim opierać. Praktyczny wymiar realizacji idei słowiańskiej solidarności referent widział w obronie „kresów Słowiańszczyzny” na łamach prasy. Miał tu na myśli przede wszystkim zagrożenie madziarskie i niemieckie, ale w dalszej części wypowiedzi wskazał także na zagrożenie wewnętrzne, jakim był brak zgody między narodowościami słowiańskimi. Dziennikarze słowiańscy zdaniem referenta powinni tłumić tego typu konflikty (jako przykłady podawał zatargi serbsko-chorwacki, polsko-ruski i polsko-czeski). Na koniec wypowiedzi przedłożył zgromadzeniu treść rezolucji, w której wytyczył trzy zadania prasy słowiańskiej: wspierać solidarność Słowian, bronić jej oraz łagodzić konflikty między narodami słowiańskimi ${ }^{60}$.

W dyskusji nad rezolucją wybrzmiały głosy skierowane zwłaszcza przeciwko propagandzie rosyjskiej i uleganiu jej przez część słowiańskiej prasy, głównie czeskiej. Zdziechowski wymieniał agitujące przeciwko Polsce gazety „Swiet” i „Moskowskije wiedomosti", wskazując że są one krytykowane nawet przez rosyjskich intelektualistów: Lwa Tołstoja, Aleksandra Pypina, Władimira Sołowjowa czy zwłaszcza prof. Borysa Cziczerina. Z kolei Jaroslav Rozvoda, redaktor „Samostatnosti”, potępił uleganie przez część czeskiej prasy wpływom rosyjskim, co wpływać miało negatywnie na relacje polsko-czeskie. Rosję skrytykował także „Rusin z pochodzenia” Eugeniusz Barwiński, wymieniając krzywdy doznawane przez ludność ruską na rosyjskiej Ukrainie $^{61}$. Ignát Hořica starał się bronić czeskie środowiska dziennikarskie. Wymieniał dowody przyjaźni polsko-czeskiej i stwierdzał, że musi dojść do pojednania rosyjsko-polskiego, które tylko w bieżącej sytuacji jest niemożliwe ${ }^{62}$.

Po Beaupré miał wystąpić Vajanský, ale z powodu odwołania jego wystąpienia, przedmówca zaproponował, by przegłosować przygotowaną przez gościa ze Słowacji rezolucję, która zdaniem autora miała prowadzić do tego, by „wzajemność” była praktyczna i duchowa. Poprzez praktyczność rozumiał: wymianę ważniejszych słowiańskich czasopism między redakcjami gazet; rekomendowanie bogatszym rodakom zakupu słowiańskich gazet; utworzenie funduszu dla młodych dziennikarzy; zaprowadzenie stałej korespondencji między słowiańskimi dziennikami. Co się tyczy aspektów duchowych, to Vajanský podkreślał, że wzajemność ma wynikać z plemiennej i kulturalnej wspólności wszystkich narodów słowiańskich bez wyjątku; co więcej, ma się objawiać wzajemną sympatią; każda z literatur ma się rozszerzać poprzez przekłady czy krytyki ${ }^{63}$.

\footnotetext{
59 Drugi Zjazd..., s. 20.

60 Ibidem, s. 24.

61 Ibidem, s. 25.

62 Ibidem, s. 26-27.

63 Ibidem, s. 27-28.
} 
Rezolucję przyjęto, a następnie uczestnicy zjazdu udali się na Wawel, po którym oprowadzał prof. Sławomir Odrzywolski oraz ks. Teofil Flis. Następnie uczestnicy zjazdu obejrzeli na krakowskich Błoniach defiladę młodzieży szkolnej przygotowaną przez dr. Henryka Jordana oraz zwiedzili Park Miejski, zapoznając się z urządzeniami gimnastycznymi, ustawionymi tam przez krakowskiego lekarza. Pierwszy dzień obrad zamknął raut w Hotelu Saskim ${ }^{64}$.

24 września posiedzenie rozpoczęto od odczytania szeregu depesz od środowisk dziennikarskich z różnych zakątków monarchii habsburskiej oraz zagranicy. Tego dnia przewidziano dwa referaty: Prokopa Gregra, redaktora „Narodnich listü” oraz dr. Augusta Sokołowskiego. Pierwszy z referentów przypomniał, że na zjeździe praskim wystąpiono z postulatem utworzenia słowiańskiego biura korespondencyjnego. Podczas swojego przemówienia w Krakowie uzasadniał potrzebę tej inicjatywy i relacjonował przebieg prac komitetu zjazdowego z Pragi nad urzeczywistnieniem tego planu. Przewidywał on utworzenie stałego biura korespondencyjnego w Pradze oraz sieci ognisk w ważniejszych miastach słowiańskich w Austro-Węgrzech. Aby jednak do tego doprowadzić, referent postulował najpierw, aby w każdym kraju wyłonić komitety, które znajdą osoby mogące zostać korespondentami ${ }^{65}$. W dyskusji nad referatem pojawiły się głosy, by uruchomić biuro korespondencyjne w Krakowie (Józef Hopcas) lub w Wiedniu (Teofil Merunowicz). Jedynie Franc Podgornik postulował odroczenie uchwały o utworzeniu biura do kolejnego zjazdu, ale jego wniosek został odrzucony ${ }^{66}$.

Ostatni referent, dr August Sokołowski, postulował utworzenie czasopisma najlepiej w języku niemieckim, wydawanego w Wiedniu, które przybliżałoby wszystkim Słowianom w monarchii habsburskiej istotne sprawy słowiańskie oraz objaśniało w rzeczowy sposób złożone problemy, z którymi borykają się poszczególne narodowości słowiańskie. Co najważniejsze, poprzez tak rozumiane dążenie do wzajemnego poznania widział drogę do utworzenia trwałego sojuszu posłów słowiańskich w Radzie Państwa w Wiedniu ${ }^{67}$.

Hovorka w dyskusji nad referatem zarzucił przedmówcy, że istnieje już takowe pismo - „Politik” wydawane w Pradze, ale sam przyznał, że jest mało spopularyzowane i jeśli powstałoby nowe czasopismo, powinno być wydawane przez planowane biuro korespondencyjne. Alfred Szczepański dodał jeszcze jeden postulat - otóż by informować prasę zagraniczną o sprawach słowiańskich, ale w językach narodowych odbiorców. W tym celu postulował, aby jak najwięcej słowiańskich towarzystw dziennikarskich przystąpiło do Międzynarodowego Związku Prasy (International Union of Press Associations) założonego w 1894 roku w Antwerpii i organizującego coroczne kongresy prasy, do którego jak dotychczas należało tylko lwowskie TDP. Szczepański twierdził, że dzięki dużej liczbie członków Słowian w Związku udałoby się stworzyć wspólną słowiańską reprezentację i wydelegować jednego słowiańskiego

\footnotetext{
64 Ibidem, s. 29-30.

65 Ibidem, s. 32-38.

66 Ibidem, s. 38-39.

67 Ibidem, s. 39-41
} 
dziennikarza do zarządu organizacji ${ }^{68}$. Były też i głosy przeciwne idei utworzenia nowego pisma. Zdziechowski twierdził, że rolę pisma ogólnosłowiańskiego odgrywa już wydawany od 1898 roku przez Adolfa Černiego „Slovanský přehled”, Podgornik zaś twierdził, że przyszłe słowiańskie biuro korespondencyjne będzie udzielało informacji, należałoby natomiast powołać słowiańskie pismo polityczne. Z kolei prof. Roman Zawiliński zaproponował, by prócz proponowanego przez Sokołowskiego niemieckojęzycznego biuletynu informacyjnego o sprawach politycznych Słowian wydawać także periodyk poświęcony życiu literacko-artystycznemu z artykułami w językach słowiańskich ${ }^{69}$.

Po zakończeniu obrad dziennikarze wysłuchali koncertu pieśni w Czytelni Akademickiej Mickiewicza na placu Wszystkich Świętych w Krakowie, zwiedzili Bibliotekę Jagiellońską w Collegium Maius, Muzeum Narodowe w Sukiennicach oraz Dom Jana Matejki ${ }^{70}$. Drugi dzień zjazdu zakończono uroczystym bankietem w Grand Hotelu. Najpierw Chyliński wzniósł oficjalny pierwszy toast za Franciszka Józefa, potem zaś Emil Bretter za Kraków, „starosławną stolicę Polski”, gdzie utwierdzono „unię słowiańskich dziennikarzy”; prezydent Friedlein za „pomyślność i wzrost dziennikarstwa słowiańskiego", aż w końcu profesor Zdziechowski wystąpił z długą przemową, wymieniając poetów, którzy urzeczywistniali jedności: czesko-słowacką, słoweńsko-chorwacką i chorwacko-serbską, polsko-ruską, a nawet wymieniał Rosjan (Pypina, Cziczerina, Sołowjowa i Tołstoja), którzy zdawali się rozumieć trudne położenie Polaków. Przypominał inicjatywy mające prowadzić do porozumienia między Polakami i Rosjanami: obchody Mickiewiczowskie zorganizowane w grudniu 1898 roku w Petersburgu i Puszkinowskie w czerwcu 1899 roku w Krakowie. Wywód ten posłużył mu do tego, by udowodnić zebranym, że Polacy nie są obojętni na sprawy słowiańskie, ale potrzebują w imię chrześcijańskiej sprawiedliwości zrozumienia dla swojego położenia w kontekście relacji z Rosją. Przywoływał Mickiewicza, który miał pokładać nadzieję w Czechach jako arbitrze w sporach polsko-rosyjskich. Podkreślił, że prawdziwym wrogiem Słowiańszczyzny są Niemcy, Madziarzy oraz ,inni Słowianie”. W końcu docenił czasopismo „Slovanský přehled” i wzniósł toast za słowiańską prasę ${ }^{71}$.

Należy zauważyć, że w zjazdowych przemówieniach Zdziechowskiego wybrzmiał bardzo mocno wątek rosyjski, z polskiego punktu widzenia będący przeszkodą w uzyskaniu pełni jedności między poszczególnymi narodowościami słowiańskimi. Na zjeździe kilkakrotnie polscy dziennikarze podkreślali swój żal do prasy innych narodów słowiańskich, że te nie potępiają Rosji za jej politykę, a wręcz chcą szukać z nią sojuszu. Zjazd w Krakowie stał się zatem okazją do zapoznania prasy zachodnio- i południowosłowiańskiej z polskim punktem widzenia na stosunki polsko-rosyjskie i ogólnie słowiańsko-rosyjskie. Jednocześnie obecność na zjeździe Zdziechowskiego, ale także Sokołowskiego i Morawskiego, wskazywała, że Polacy nie są nieprzejednanymi wrogami Rosji jako takiej, wszak wymienieni uczeni sami

\footnotetext{
68 Ibidem, s. 42.

69 Ibidem, s. 43.

70 Ibidem, s. 43-44.

71 Ibidem, s. 45-49.
} 
byli zaangażowani w szukanie porozumienia z rosyjskimi intelektualistami, czego najlepszym dowodem była organizacja przez nich uprzednio obchodów Puszkinowskich w Krakowie ${ }^{72}$. Rzecz znamienna, że wspominani przez Zdziechowskiego Cziczerin czy Pypin już w 1900 roku otrzymają doktorat honoris causa krakowskiej wszechnicy.

Po Zdziechowskim toast za prawicę w Radzie Państwa jako tą, która jest w stanie zrealizować postulat równouprawnienia i polepszenia położenia słowiańskich narodów, wzniósł Włodzimierz Jaworski. W imieniu Chorwatów i Słoweńców wystąpił ks. Biankini, który uważał, że organizacja zjazdu przypadła na czas przesilenia rządowego, co jego zdaniem było omenem. Twierdził, że Słowianie nie potrzebują już opiekunów, powinni sami, w sojuszu z sobą, wziąć politykę w swoje ręce. Ufność swą pokładał właśnie w polskich politykach w Wiedniu. Zajączkowski z kolei wzniósł toast za Karla Riegera, za co odwdzięczył się Hovorka, podnosząc kielich za Juliana Dunajewskiego. Potem przemówił dr Šime Mazzura z Zagrzebia, powołując się na historię biblijną, jak Jezus rozwiązał usta niememu, mówiąc mu „Efeta!’. Gość z Chorwacji porównał tym samym siebie do niemego z Nowego Testamentu, bowiem „liberalizm węgierski odebrał mi mowę, ale obecne zebranie nie jest zjazdem - tu nie wiąże mnie kaganiec". Słowa gościa z Zalitawii wywołały brawa; ten zaś podkreślał doniosłość narodów polskiego oraz czeskiego zwłaszcza w kontekście walki tego drugiego z zagrożeniem niemieckim. Za Słowaków wzniósł natomiast toast August Sokołowski, nieskromnie przypominając, że w średniowieczu polskie państwo sięgało na drugą stronę Karpat, a następnie podkreślając, że Polsce należy się pierwszeństwo $\mathrm{w}$ głoszeniu idei słowiańskiej z racji na umiłowanie wolności przez polski naród. Ciekawą mowę wygłosił Włodzimierz Lewicki, przypominając Zjazd Słowiański w Pradze, w którym upatrywał momentu, kiedy ,rozpoczął się plemienny bój Słowian z Niemcami”. Wspomniał manifest uchwalony w 1848 roku, uznając go za ,promień światła, co przez pół wieku oświecał i ogrzewał nasze dusze, prostował nasze drogi w mozolnym pochodzie, osładzał niedolę klęsk i zawodów, aż dowiódł nas do epoki nowego pobratania, do otuchy, odwagi, chęci do czynu”. Wzniósł następnie toast za autorów porozumienia sprzed pół wieku. Wznoszono jeszcze inne toasty w duchu braterstwa i przyjaźni ${ }^{73}$.

Po bankiecie goście udali się do Teatru Miejskiego, gdzie przygotowano uroczyste przedstawienie, składające się z aż trzech sztuk: komedii Jarosława Vrchlickiego w przekładzie Włodzimierza Stebelskiego pt. W beczce Dyogenesa; I aktu Mazepy Juliusza Słowackiego oraz obrazu historycznego według scenariusza Władysława Ludwika Anczyca (ps. „A.W. Lasota”) pt. Kościuszko pod Racławicami. W przedstawieniach wzięli udział znani krakowscy aktorzy z Ludwikiem Solskim na czele ${ }^{74}$. Stale śledzący przebieg zjazdu dyrektor policji Korotkiewicz był obecny również

72 Szerzej o poglądach i zaangażowaniu Zdziechowskiego w szukanie polsko-rosyjskiego porozumienia zob. Z. Opacki, W kręgu Polski, Rosji i Stowiańszczyzny. Myśl i działalność społeczno-polityczna Mariana Zdziechowskiego do 1914 roku, Gdańsk 1996, s. 120-127.

73 Treść wszystkich przemów w: Drugi zjazd..., s. 45-60.

74 Biblioteka Narodowa w Warszawie, sygn. DŻS XIXA 7 [Afisz teatralny Teatru Miejskiego w Krakowie z powodu Zjazdu Dziennikarzy Słowiańskich w dniu 24 IX 1899]. 
w teatrze. Nie omieszkał odnotować, że w trakcie antraktu między sztukami Platon Kostecki z balkonu wezwał publiczność, by słowiańskich gości uczciła okrzykami „Niech żyją!”, na co ktoś odkrzyknął „To są moskalofile! banda łotrów!”. Wtedy widownia powstała z miejsc i oklaskami zagłuszyła okrzyki i w ten sposób okazała cześć gościom ${ }^{75}$.

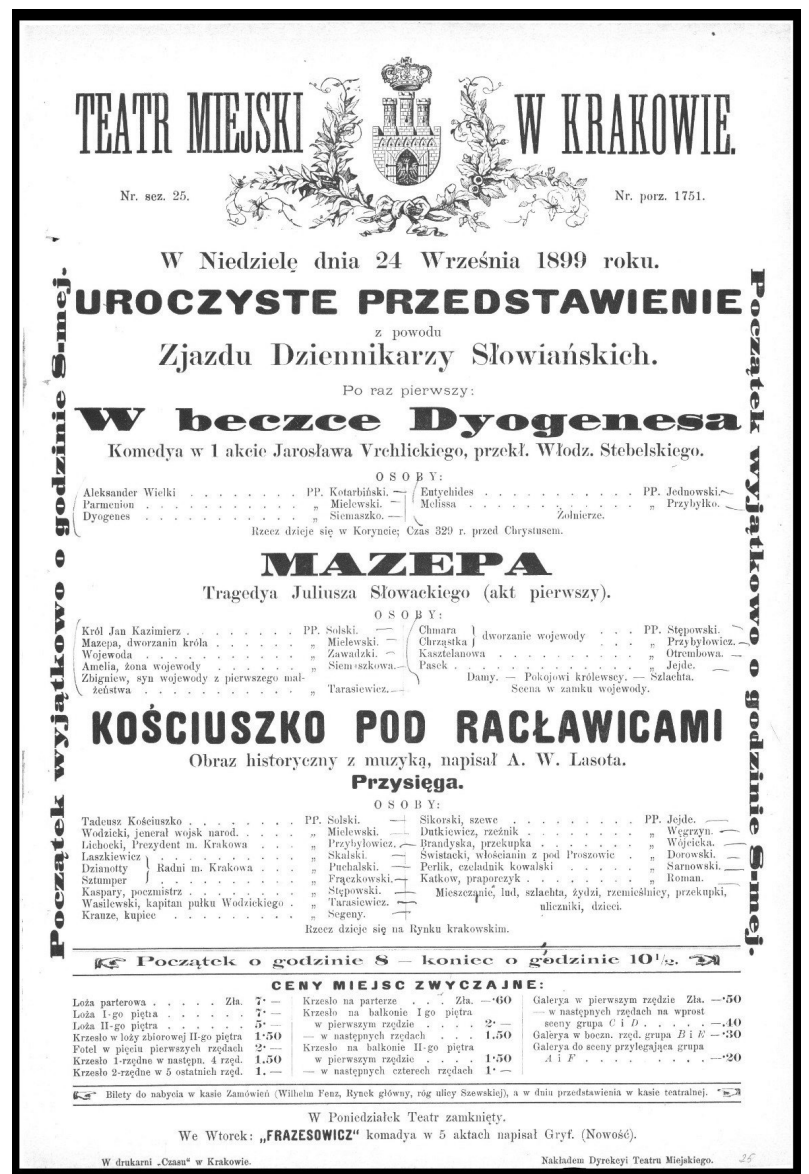

Il. 3. Afisz teatralny Teatru Miejskiego w Krakowie z powodu Zjazdu Dziennikarzy Słowiańskich w dniu 24 IX 1899

Źródło: Biblioteka Narodowa w Warszawie, sygn. DŻS XIXA 7.

Ostatni dzień zjazdu rozpoczął się od oficjalnego złożenia hołdu Adamowi Mickiewiczowi poprzez złożenie wieńców pod pomnikiem przez delegacje czeską i chorwacką, a następnie dziennikarze udali się do Rady Miasta, by kontynuować obrady. 


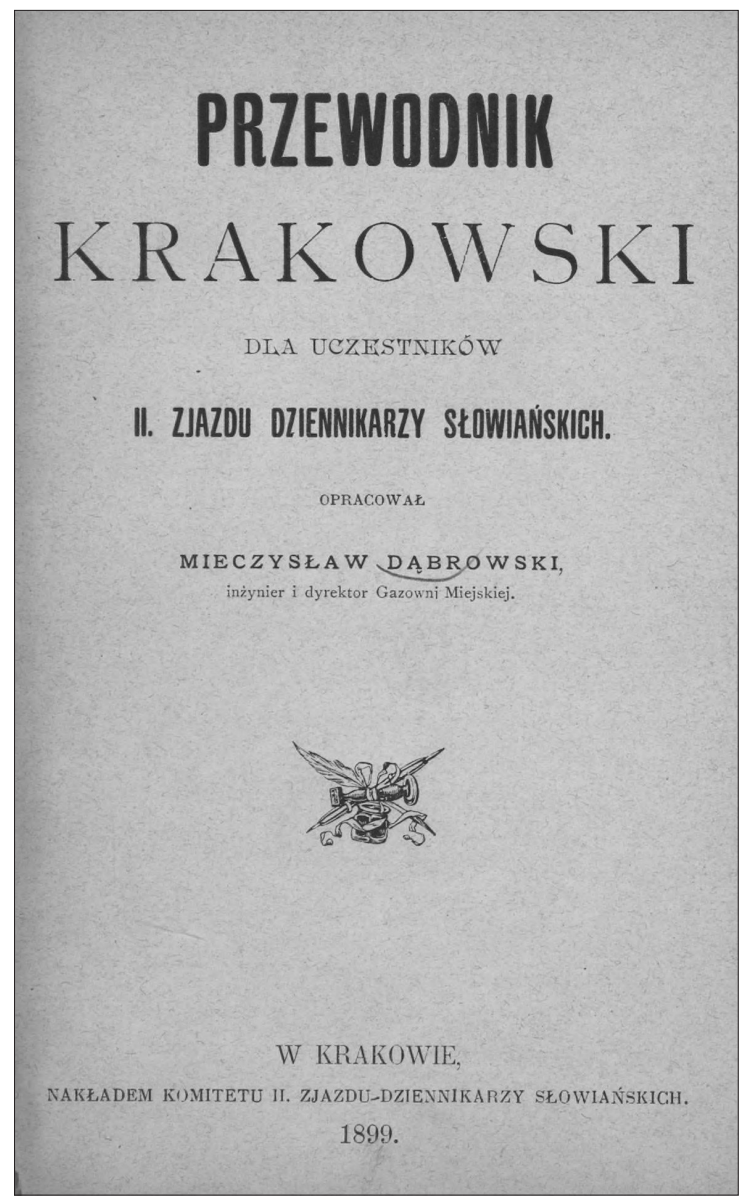

I1. 4. Strona tytułowa Przewodnika krakowskiego dla uczestników II. Zjazdu Dziennikarzy Stowiańskich autorstwa Mieczysława Dąbrowskiego (Kraków 1899)

Źródło: Biblioteka Jagiellońska.

Po odczytaniu nadesłanych telegramów od różnych osobistości przystąpiono do wysłuchania ostatniego referatu na zjeździe - Františka Hovorki pt. „W sprawie utworzenia Związku Dziennikarzy Słowiańskich w Austro-Węgrzech". Autor wnioskował, by powołać specjalny komitet, składający się z dwuosobowych reprezentantów każdej narodowości, który opracuje statut przyszłego słowiańskiego stowarzyszenia dziennikarskiego. Według Hovorki mógłby do niej należeć każdy słowiański dziennikarz mieszkający i pracujący w monarchii habsburskiej ${ }^{76}$. W ostatniej części obrad Ostaszewski-Barański sformułował wniosek, aby komitet zjazdowy po otrzymaniu

76 Drugi zjazd..., s. 61-63. 
odpowiedzi od namiestnictwa na rekurs przeciwko decyzji policji o uniemożliwieniu czynnego udziału dziennikarzy z Zalitawii, przeprowadził procedurę odwoławczą przez wszystkie instancje. Ponadto Szczepański wnioskował o wydanie księgi pamiątkowej ze zjazdu, z której sprzedaży środki miały zostać przeznaczone na organizację kolejnego kongresu. Jednogłośnie przyjęto propozycję Chylińskiego, by gospodarzem III Zjazdu Dziennikarzy Słowiańskich był chorwacki, a więc zalitawski, Zagrzeb $^{77}$.

Na koniec zjazdu komitet zorganizował dla jego uczestników wycieczkę do kopalni soli w Wieliczce. Warto też podkreślić, że poza programem oficjalnym zachęcano także uczestników kongresu do samodzielnego zwiedzania Krakowa. W tym celu wydano dedykowany gościom praktyczny Przewodnik krakowski, autorstwa inż. Mieczysława Dąbrowskiego, dyrektora Gazowni Miejskiej ${ }^{78}$.

\section{OPINIE O ZJEŹDZIE}

W opinii większości polskich dzienników zaangażowanych w organizację kongresu, zjazd zakończył się sukcesem. Podobnie wyidealizowany obraz przedstawiła publikacja wydana w 1900 roku jako pokłosie kongresu ${ }^{79}$. Ale zjazd przebiegł też w atmosferze ataków ze strony socjalistów. W trakcie trwania zjazdu na Rynku Głównym w Krakowie została zorganizowana demonstracja robotników wymierzona przeciwko uczestnikom kongresu, pomnik Mickiewicza przyozdobiono czerwoną wstęgą, a w mieście (w tym na budynkach, w których swoje siedziby miały redakcje gazet organizujących zjazd) rozwieszono plakaty z napisami „Precz z pismakami moskalofilskimi”. Ogólnie oskarżano krakowskich dziennikarzy o wspieranie panslawizmu poprzez zaproszenie do Krakowa „moskalofilów słowiańskich”. Demonstrację rozpędziła krakowska policja. Dzienniki zaangażowane w organizację zjazdu doszukiwały się w tych wydarzeniach inspiracji żydowskiej albo niemieckiej, które to siły miały poczuć się zagrożenie z powodu rozwijającej się współpracy Słowian w monarchii ${ }^{80}$. Socjalistyczny „Naprzód” bez ogródek pisał, że „Zjazd panslawistyczny skończył się po trzech dniach pijatyki za pieniądze miasta Krakowa, odjęte od ust biedaków” i wzywał czytelników, by zbierali składki na „ofiary” demonstracji (nazywanej w socjalistycznej prasie „spacerem”), czyli schwytanych i poturbowanych przez policję manifestantów ${ }^{81}$.

77 Ibidem, s. 63-64.

78 M. Dąbrowski, Przewodnik krakowski dla uczestników II. Zjazdu Dziennikarzy Słowiańskich, Kraków 1899.

79 Drugi Zjazd...

80 „Głos Narodu”, 25 IX 1899, nr 217, s. 3; „Dziennik Polski”, 28 IX 1899, nr 269, s. 1.

81 „Naprzód”, 28 IX 1899, nr 39, s. 1-2. 
Suchej nitki na organizatorach zjazdu nie zostawił także satyryczny „Djabeł”. W numerze z 1 października 1899 roku zamieszczono wiersz Nasza polityka, w którym ukazano, że część polskiej prasy („Słowo Polskie”) chce trzymać z Niemcami, a pozostałe gazety (organizujące zjazd) z Czechami. Tymczasem „Djabel” wzywał, by skupić się na dążeniu do własnych celów:

Mój Polaku, mój rodaku,

Toć to przecie jest curiosum,

Żeby tylko oprócz ciebie

Wszyscy inni mieli rozum.

Niemiec pragnie być na górze,

Więc to rzeczą wcale jasną,

Że uprawia politykę

Wszechniemiecką, swoją własną.

Czech nie pragnie być na dole,

Więc na Niemca wznosi krzyki

I każdego nawołuje

Do swej czeskiej polityki.

Ty jedyny, kontuszowy,

Czy frakowy, mój szlachcicu,

Umieściłeś politykę

Własną, polską... na księżycu.

Nigdy nie masz własnej woli,

Służysz tylko zawsze, wszędzie

Czechom, Niemcom, byle djabłu,

Kto zawoła - za narzędzie.

Wstydź się, wstydź się, mój szlachcicu,

Cudze kąty wciąż wycierać,

Zawsze służyć cudzym bogom,

Dać się wszystkim poniewierać.

Rób co będzie z twojem dobrem:

Dla honoru i logiki,

Wywieś sztandar swojej własnej

Czysto polskiej polityki! ${ }^{82}$

Na łamach „Djabła” zamieszczono też opis przebiegu zjazdu w formie opisu sztuki teatralnej, a dokładniej mówiąc „farsy w 4 aktach, 10 odsłonach, z muzyką, tańcami i bufetem” na „benefis Michała Chylińskiego a kosztem gminy m. Krakowa”"83. W sztuce tej wyśmiano, że Chyliński, sam marzący o mandacie poselskim, organizacją zjazdu wysłużył się stańczykom. Tymczasem zaproszeni na zjazd goście w rzeczywistości okazali się (z wyjątkiem jednego Jaroslava Rozvody) moskalofilami. Komedię kończył opis odjazdu gości z Krakowa, którzy „śmieją się w wagonach z naiwności Polaków, śpiewają: «Boże caria chrani» [...]»"4.

\footnotetext{
82 Nasza polityka, „Djabeł”, 1 X 1899, nr 19, s. 1.

83 Ibidem, s. 2-3.

84 Ibidem, s. 3.
} 


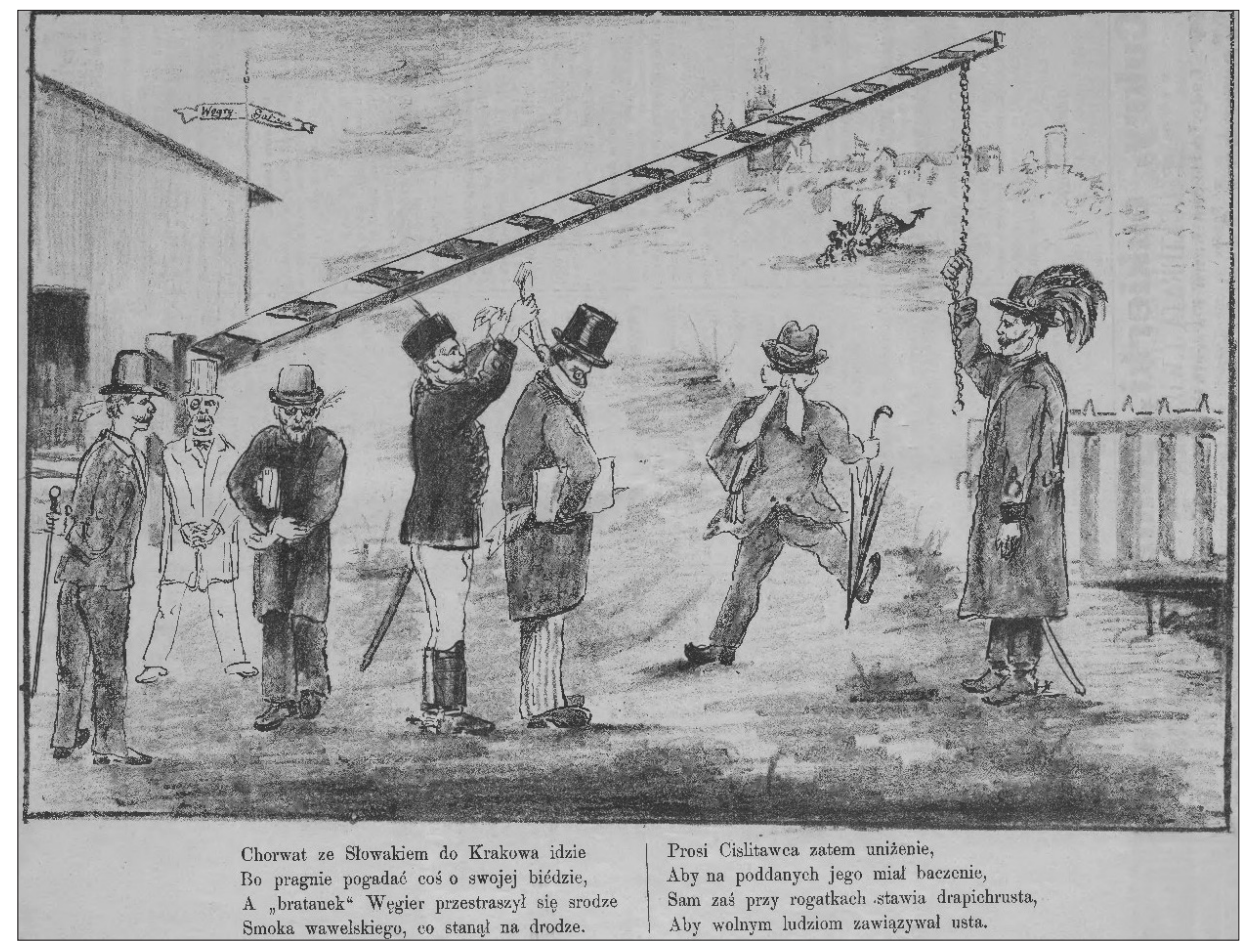

Il. 5. Karykatura wyśmiewająca działania władz austriackich i węgierskich podczas II Zjazdu Dziennikarzy Słowiańskich w Krakowie

Źródło: „Djabeł”, 1 X 1899, nr 19, s. 4.

O zjeździe wypowiadała się także prasa poszczególnych narodów słowiańskich. Zbiorcza analiza tych opinii, pisanych w różnych językach, mogłaby być przedmiotem odrębnego studium. Jak dotychczas, w nauce drobiazgowo przeanalizowano tylko reakcje chorwackiej prasy na zjazd ${ }^{85}$. Slaven Kale w swoim opracowaniu wykazał, że pozytywnie o zjeździe pisały przede wszystkim te dzienniki chorwackie, które były reprezentowane przez swoich redaktorów na zjeździe („Obzor”, „Hrvatska domovina"). Podkreślał, że relacje publikowane na łamach tychże gazet dużo uwagi poświęciły wykluczeniu zalitawskich dziennikarzy z czynnego udziału w obradach. Pojawiła się nawet teza, że źródłem tej decyzji miały być władze chorwackie obawiające się, aby kolejny zjazd nie odbył się w Zagrzebiu ${ }^{86}$. Niewątpliwie teza ta wymagałaby weryfikacji w chorwackich i wiedeńskich archiwach. Wszak bowiem kolejny zjazd, zaplanowany na 1900 rok w Zagrzebiu, został później zakazany i faktycznie się nie odbył. Autor ukazał jednak także negatywne opinie o zjeździe publikowane na łamach prasy prorządowej („Narodne novine”, „Agramer Zeitung”, ale i „Hrvatske pravo"). Określano imprezę jako upolitycznioną, a chorwackich dziennikarzy

85 S. Kale, op. cit., s. 39-53.

86 Ibidem, s. 43-48. 
uważano za zaślepionych ideą wzajemności słowiańskiej, która niczego dobrego im nie przyniesie. Popierano tym samym decyzję o zakazie udziału zalitawskich dziennikarzy w zjeździe ${ }^{87}$.

W czeskim „Slovanskim přehledzie” opublikowano natomiast sprawozdanie z kongresu, w którym zauważono, że w zjeździe nie wzięli udziału Rusini dystansujący się „od wszystkiego, co od Polaków pochodzi”; podkreślano, że przeważali liczebnie dziennikarze polscy i czescy; w końcu odnotowano kłopoty zalitawskich Słowian, którym uniemożliwiono zabierać głos na kongresie ${ }^{88}$. Oprócz sprawozdania w roczniku opublikowano także list otwarty Mariana Zdziechowskiego w języku czeskim, w którym wyłożył swoje poglądy na temat stosunków polsko-rosyjskich, a także przypomniał ważniejsze przemowy uczestników zjazdu ${ }^{89}$. Wspominał także, że na zjeździe był obecny tylko jeden Słoweniec, zabrakło Serbów, a Rusini, chociaż byli, to jednak nie było redaktorów ruskich gazet ${ }^{90}$.

$\mathrm{Na}$ publikację Zdziechowskiego niemal natychmiast zareagował Iwan Franko, pisząc list do redaktora „Slovanskiego přehledu”, Adolfa Černego, w którym zgłosił mu, że on również chce opublikować otwarty list $\mathrm{z}$,powodu tych bredni i faryzejskich fraz, którymi krakowscy Polacy zniweczyli ideę słowiańskiej wzajemności"91. Próbował udowodnić adresatowi, że ci, których Zdziechowski w swojej wypowiedzi wymieniał jako Rusinów, to w rzeczywistości ,,perekinczyki” - „najciężsi wrogowie rozwoju Rusinów, zaprzedane dusze”. Miał tu na myśli przede wszystkim gente Rutheni, natione Poloni: Platona Kosteckiego, Teofila Merunowicza oraz ,ppodłe indywiduum” - jak się wyraził - Eugeniusza Barwińskiego. Na koniec pouczył swojego adresata, że ,nie tak rozumieli słowiańską wzajemność ojcowie słowiańskiego odrodzenia" "92. Również najważniejsze dzienniki ruskie pozostawały niechętne organizatorom zjazdu. Rusofilski „Hałyczanyn” miał wypominać, że udział w kongresie mogli wziąć tylko ci dziennikarze, których rekomendowało TDP, przez co Rusini nawet nie starali się o to. Jako autorytet przywoływano ks. Stojałowskiego, który miał krytykować organizatorów zjazdu za ich stosunek do Rusinów. Kąśliwe uwagi miało zamieszczać także „Diło”, jedynie ugodowy „Rusłan” opublikował - jak pisano w „Czasie” - „obiektywne sprawozdania” z obrad ${ }^{93}$.

Nieobecność Rusinów na zjeździe, spowodowana konfliktem polsko-ruskim, została odnotowana także po drugiej stronie Karpat przez słowackie „Národnie noviny”, w której to gazecie opublikowano relację autorstwa Jozefa Kuffnera, redaktora praskich „Narodnich listů" ${ }^{4}$. Zresztą gazeta podkreślała także nieobecność Serbów

87 Ibidem, s. 47-50.

88 „Slovanský přehled”, R. 2, 1900, s. 88-91.

89 M. Zdziechowski, Po sjezdĕ slovanských novinárů v Krakově. Z dojmů slovanofila, „Slovanský přehled", R. 2, 1900, s. 91-99.

90 Ibidem, s. 98.

91 І. Франко, Зібрання творів у п ятдесяти томах, т. 50: Листи (1895-1916), Київ 1986, s. 143.

92 Ibidem, s. 144.

93 Za: „Czas”, 29 IX 1899, nr 222, s. 2.

94 „Národnie noviny”, 30 IX 1899, nr 115, s. 2; 3 X 1899, nr 116, s. 2; 7 X 1899, nr 118, s. 1-2; 12 X 1899, nr 120, s. 1-2. 
oraz zakaz występowania jako czynnym uczestnikom zjazdu Słowakom i zalitawskim Chorwatom. Autor opisywał też zamieszki na ulicach Krakowa wywołane przez socjalistów przeciwnych zjazdowi ${ }^{95}$.

\section{ZAKOŃCZENIE}

Po zjeździe pozostało przede wszystkim wrażenie możliwości stworzenia wspólnego słowiańskiego frontu $\mathrm{w}$ monarchii (zwłaszcza silnie wybrzmiały sympatie polsko-czeskie i polsko-chorwackie), pozostał jednak niesmak związany z decyzją o odsunięciu od czynnego uczestnictwa zalitawskich dziennikarzy. Dlatego też w następnych dniach po zakończeniu zjazdu przeciwko decyzji namiestnika komitet organizacyjny wystąpił na drodze prawnej do ministerstwa spraw wewnętrznych. Sprawa ciągnęła się aż do końca stycznia 1900 roku, kiedy Chyliński uzyskał odpowiedź od radcy rządu i dyrektora policji Korotkiewicza o odrzuceniu rekursu komitetu przez ministerstwo $0^{96}$. Dziennikarze nie uzyskali więc satysfakcji.

Również najważniejszych zamierzonych na zjeździe krakowskim celów słowiańscy dziennikarze nie osiągnęli, przynajmniej natychmiast. Najbardziej praktycznym z postulatów była chęć utworzenia słowiańskiej agencji prasowej mającej być alternatywą dla Wiedeńskiego Biura Korespondencyjnego. Tymczasem nie tylko nie udało się tejże agencji założyć, ale na dodatek wiedeńskie biuro, posiadające od 1 grudnia 1898 roku swoją filię we Lwowie, 1 grudnia 1901 roku założyło kolejną w Krakowie. Podobnie nie udało się założyć pisma informującego o sprawach słowiańskich. Dopiero w 1905 roku Feliks Koneczny rozpocznie wydawanie „Świata Słowiańskiego", wielofunkcyjnego w rzeczywistości pisma, spełniającego także rolę biuletynu informującego o sprawach słowiańskich ${ }^{97}$. W 1902 roku na IV Zjeździe Dziennikarzy Słowiańskich w Lublanie powiedzie się natomiast powołanie Związku Słowiańskich Stowarzyszeń Dziennikarskich, na którego czele jako prezes stanie Michał Chyliński, a do jego wydziału wejdzie aż pięciu polskich dziennikarzy ${ }^{98}$. Wymiernym rezultatem zjazdów, zarówno praskiego, jak i krakowskiego, było jednak przede wszystkim zapoczątkowanie regularnych zjazdów, przez które przewinęły się setki słowiańskich dziennikarzy nawiązujących z sobą długoletnią niekiedy współpracę. II Zjazd Dziennikarzy Słowiańskich w Krakowie pokazał również, że aspiracje polskiego (i nie tylko polskiego) dziennikarstwa wykraczały o wiele dalej poza granice wyznaczone charakterem uprawianej profesji. Zaangażowani w organizację zjazdu dziennikarze jasno bowiem artykułowali swoje cele polityczne, co od samego

95 „Národnie noviny”, 30 IX 1899, nr 115, s. 2.

96 ЦДІАУЛ, ф. 146, оп. 7, спр. 4771, k. 20-22; Drugi Zjazd..., s. 70-76.

97 J. Myśliński, Prasa Galicji w dobie autonomicznej 1867-1918, Warszawa 1972, s. 54, 56.

98 Sprawozdanie Towarzystwa Dziennikarzy Polskich we Lwowie za czas od dnia 1. kwietnia 1902 roku do dnia 30. kwietnia 1903 roku [...], Lwów 1903, s. 6. 
początku wywołało zainteresowanie władz państwowych i przyczyniło się do otoczenia krakowskiego zjazdu policyjną kontrolą.

\section{BIBLIOGRAFIA}

\section{Źródła}

\section{Źródła archiwalne}

Archiwum Narodowe w Krakowie (ANKr.)

zesp. 29/247: C.K. Dyrekcja Policji w Krakowie, sygn. 56: Akta prezydialne (1902, nr 17-1058),

346/902: Zjazd Dziennikarzy Słowiańskich w Krakowie 1899-1902.

zesp. 29/576/0: Obchody i uroczystości krakowskie - zbiór szczątków zespołów akt komitetów obchodów,

sygn. 43: Akta różnych uroczystości krakowskich (pogrzeby, obchody, jubileusze, zjazdy), teka 13: Zjazd Dziennikarzy Słowiańskich.

sygn. 151: Zjazd Dziennikarzy Słowiańskich, II Zjazd w Krakowie 1899.

Biblioteka Narodowa w Warszawie

sygn. DŻS XIXA 7: [Afisz teatralny Teatru Miejskiego w Krakowie z powodu Zjazdu Dziennikarzy Słowiańskich w dniu 24 IX 1899].

Центральний державний історичний архів України у Львові (ЦДІАУЛ)

ф. 146: Галицьке намісництво,

оп. 6 ,

спр. 1275: Донесення, листування, звіти та інші документи таємного діловодства президіального відділу, 1899;

оп. 7 ,

спр. 4771: Переписка с Дырекцией полиции и комитетом по организации

II сьезда представителей словянской пресы о запрещении полицией проведення пресы в Кракове 1899.

ф. 466: Товариство польських журналістів, м. Львів,

оп. 1 ,

спр. 11: Звіт про діялність товариства за 1899-1900 pp.

\section{Źródła drukowane}

Dąbrowski M., Przewodnik krakowski dla uczestników II. Zjazdu Dziennikarzy Słowiańskich, Kraków 1899.

Drugi Zjazd Dziennikarzy Stowiańskich w Krakowie, Kraków 1900.

Sprawozdanie Towarzystwa Dziennikarzy Polskich we Lwowie za czas od dnia 17. kwietnia 1898 roku do dnia 14. maja 1899 roku [...], Lwów 1899.

Sprawozdanie Towarzystwa Dziennikarzy Polskich we Lwowie za czas od dnia 1. kwietnia 1902 roku do dnia 30. kwietnia 1903 roku [...], Lwów 1903. 
Zdziechowski M., Druhý sjezd slovanských novinářu v Krakově, „Slovanský přehled”, R. 2, 1900, s. 88-91.

Wydawnictwa źródłowe

Korešpondencia Svetozára Hurbana Vajanského II (Výber listov z rokov 1890-1916), ed. P. Petrus, Bratislava 1972.

Франко І., Зібрання творів у п ятдесяти томах, т. 50: Листи (1895-1916), Київ 1986.

Prasa

„Czas” (Kraków) 1899.

„Djabel” (Kraków) 1899.

„Dziennik Polski” (Lwów) 1899.

„Gazeta Lwowska” (Lwów) 1899.

„Gazeta Narodowa” (Lwów) 1899.

„Głos Narodu” (Kraków) 1899.

„Naprzód” (Kraków) 1899.

„Národnie noviny” (Turčiansky Svätý Martin) 1899.

„Nový život” (Nový Jičín) 1899.

„Nowa Reforma” (Kraków) 1899.

„Nowości Illustrowane” (Kraków) 1906.

„Slovanský přehled” (Praha) 1900.

„Słowo Polskie” (Lwów) 1899.

\section{Opracowania}

Agičić D., Hrvatsko-češki odnosi na prijelazu iz 19. u 20. stoljeće, Zagreb 2000.

Agičić D., Hrvatski tisak o proslavi stote obljetnice rođenja Františeka Palackoga i Prvom kongresu slavenskih novinara Austro-Ugarske u Pragu 1898. godine [w:] Spomenica Ljube Bobana 1933.-1994., ured. I. Goldstein, M. Kolar-Dimitrijević, M. Maticka, Zagreb 1996, s. 223-235.

Agičić D., Slavenski novinarski kongresi 1903.-1908. godine [w:] Spomenica Filipa Potrebice, uredila M. Matijević Sokol, Zagreb 2004, s. 321-330.

Bylina S. [et al.], Stosunki literackie polsko-czeskie i polsko-stowackie 1890-1939, red. J. Śleziński, Wrocław-Warszawa-Kraków-Gdańsk 1978.

Douša J., Sjezd slovanských novinárů v Plzni v roce 1903 [w:] „, Slavme slavně slávu Slávóv slavných”. Slovanství a česká kultura 19. století. Sborník přispěvků z 25. sympozia k problematice 19. století, Plzeñ, 24.-26. února 2005, připr. Z. Hojda, M. Ottlová, R. Prahl, Praha 2006, s. 92-94.

Gantar Godina I., Ljubljana - gostiteljica 4. vseslovanskega časnikarskega kongresa maja 1902, „Kronika” (Ljubljana), letnik 50, 2002, s. 375-384.

Gantar Godina I., Neoslavizem in Slovenci, Ljubljana 1994.

Gantar Godina I., Ob 100. obletnici VIII. vseslovanskega časnikarskega kongresa septem- 
bra 1908 w Ljubljani, „Kronika” (Ljubljana), letnik 57, 2009, s. 455-464.

Gruchała J., Koło Polskie w austriackiej Radzie Państwa wobec kwestii czeskiej i Śląka Cieszyńskiego (1879-1899), Wrocław [et al.] 1982.

Kodajová D., Rusko v slovenskej politike na prelome 19. a 20. storočia. Vajanský verzus Masaryk [w:] T. Ivantyšynová [a kol.], Mýtus, stereotyp, obraz. Rusko v slovenských dejinách a kultúre, Bratislava 2011, s. 15-28.

Kale S., „Poljaci, naša braća na sjeveru”. Hrvatska javnost o Poljacima 1860-1903, Zagreb 2018.

Leśnodorska A., Mleczkówna Z., Pomnik Adama Mickiewicza w Krakowie [w:] Kraków Mickiewiczowi, red. D. Rederowa, Kraków 1956, s. 89-177.

Myśliński J., Prasa Galicji w dobie autonomicznej 1867-1918, Warszawa 1972.

Opacki Z., W kręgu Polski, Rosji i Słowiańszczyzny. Myśl i działalność społeczno-polityczna Mariana Zdziechowskiego do 1914 roku, Gdańsk 1996.

Szymczak D., Galicyjska ,ambasada” w Wiedniu. Dzieje ministerstwa dla Galicji 18711918, Poznań 2013.

Toczek A., Towarzystwo Dziennikarzy Polskich we Lwowie (1893-1918) [w:] KrakówLwów. Książki, czasopisma, biblioteki XIX i XX wieku, t. 6, cz. 2, red. J. Jarowiecki, Kraków 2003, s. 125-140.

Toczek A., Zwiazek Dziennikarzy Polskich we Lwowie (1909-1914) jako pierwsza korporacja dziennikarska o charakterze ogólnopolskim [w:] Kraków-Lwów. Książki, czasopisma, biblioteki, t. 7, red. H. Kosętka, Kraków 2005, s. 428-443.

Vyšný P., Neo-Slavusm and the Czechs 1898-1914, Cambridge 1977. 